\title{
Cystathionase deficiency in fibroblast cultures from a patient with primary cystathioninuria
}

\author{
A. H. BITTLES and NINA A. J. CARSON \\ Research Laboratory, Department of Child Health, The Queen's University of Belfast
}

Familial cystathioninuria is a rare, hereditary amino-acid disorder with an autosomal, recessive pattern of inheritance (Harris, Penrose, and Thomas, 1959; Frimpter, 1972). There is no consistent clinical picture associated with the condition but rather a mixture of mental, neurological, and somatic disorders and indeed healthy and mentally normal children have also been described (Perry et al, 1968; Scott et al, 1970; Lyon, Procopis, and Turner, 1971). Diagnosis is made on the basis of elevated plasma cystathionine levels and excessive urinary cystathionine excretion. In the majority of cases it has proved possible to correct these biochemical abnormalities by oral pyridoxine administration. This enables the patients to handle a methionine load more efficiently and causes a decrease in the plasma and urinary cystathionine levels with a concomitant increase in urinary sulphate excretion (Frimpter, Haymovitz, and Horwith, 1963; Frimpter et al, 1967), however, variations in the degree of response to pyridoxine have been reported (Berlow, 1966; Scott et al, 1970).

The nature of the defect was established by Frimpter, and Laster et al in 1965 by demonstrating a specific deficiency of hepatic cystathioninase activity in patients with cystathioninuria, thus explaining the abnormal tissue levels of cystathionine found in such patients (Harris et al, 1959; Brenton, Cusworth, and Gaull, 1965).

Case History. S. C. was admitted to hospital at $2 \frac{1}{2}$ months of age with a history of recent recovery from a bout of gastroenteritis and with a respiratory infection associated with vomiting. Mild hepatosplenomegaly was present. His symptoms gradually cleared. He is now 3 years of age and apart from repeated chest infections has remained well with normal developmental milestones. On his first admission he was found to excrete large amounts of cystathionine in the urine which disappeared with oral administration of pyridoxine (20 mg daily) but reappeared when the therapy ceased.

\section{Materials and Methods}

Skin samples were obtained from non-cystathioninuric control subjects and from S.C. by pinch biopsy from the fore-arm. The cell lines were cultured in Minimal Essential Medium (Glasgow modification) supplemented with $10 \%$ fetal bovine serum (Flow Laboratories). Penicillin $(100 \mathrm{u} / \mathrm{ml}$.) and streptomycin $(110 \mathrm{u} / \mathrm{ml}$.) were routinely incorporated into the medium.

Cystathionase assays were carried out according to the method of Gaull, Rassin, and Sturman (1969), cystathionine synthase activity was determined by the method of Mudd et al (1965) and methionine-activating enzyme activity measured using a modification of the method of Cantoni and Durrell (1957). The total protein concentration was estimated according to the technique of Lowry et al (1951).

\section{Results and Discussion}

The results are reproduced in the Table. The skin fibroblasts cultured from S.C. had cystathionine synthase and methionine-activating enzyme activity levels within the control range. Cystathionase activity measured in a reaction mix containing 0.125 micromol of pyridoxal-5-phosphate in $0.5 \mathrm{ml}$. was $15 \%$ of the mean control value. This is higher than the levels of hepatic cystathionase activity reported by Finkelstein et al (1966) with their patient but in agreement with the findings of Tada et al (1968). Values for cystathionase activity have not previously been reported in skin fibroblast cultures, although Eagle, Piez, and Oyama, (1961) confirmed the existence of the trans-sulphuration pathway in their

TABLE

\begin{tabular}{l|c|c|c}
\hline \multicolumn{1}{c|}{ Subject } & Cystathionase & $\begin{array}{c}\text { Cystathionine } \\
\text { Synthase }\end{array}$ & $\begin{array}{c}\text { Methionine- } \\
\text { activating } \\
\text { Enzyme }\end{array}$ \\
\hline S.C. & 1.0 & $14 \cdot 1$ & 16.3 \\
Controls & 8 & 10 & 8 \\
Number & $3 \cdot 2-16 \cdot 1$ & $7 \cdot 2-37 \cdot 5$ & $7 \cdot 0-32 \cdot 6$ \\
Range & $6 \cdot 6$ & $21 \cdot 3$ & $24 \cdot 8$ \\
Mean & $5 \cdot 8$ & $20 \cdot 9$ & 28.7 \\
\hline Median & 5 &
\end{tabular}

All activities are expressed in $\mathrm{mg} /$ nanomol protein $/ \mathrm{hr}$. 
serially propagated human cell lines. The use of skin fibroblast cultures in the diagnosis and investigation of several of the inborn errors of metabolism has been documented. The above results indicate that this technique may be successfully employed in the study of familial cystathioninuria.

\section{REFERENCES}

Berlow, S. (1966). Studies in cystathionemia. American fournal of Diseases of Children, 112, 135-142.

Brenton, D. P., Cusworth, D. C., and Gaull, G. E. (1955). Homocystinuria. Biochemical studies of tissues including a comparison with cystathioninuria. Pediatrics, 35, 50-56.

Cantoni, G. L. and Durell, J. (1957). Activation of methionine for transmethylation II. The methionine-activating enzyme: studies on the mechanism of the reaction. Fournal of Biological Chemistry, 225, 1033-1048.

Eagle, H., Piez, K. A., and Oyama, V. I. (1961). The biosynthesis of cystine in human cell cultures. Fournal of Biological Chemistry, 236, 1425-1428.

Finkelstein, J. D., Mudd, S. H., Irreverre, F., and Laster, L. (1966). Deficiencies of cystathionase and homoserine dehydratase activities in cystathioninuria. Proceedings of the National Academy of Sciences, 55, 865-872.

Frimpter, G. W. (1965). Cystathioninuria: nature of the defect. Science, 149, 1095-1096.

Frimpter, G. W. (1972). Cystathioninuria, sulfite oxidase deficiency and ' $\beta$-mercaptolactate-cysteine disulfiduria'. In The Metabolic Basis of Inherited Disease, 3rd edition, ed. by J. B. Stanbury, J. B. Wyngaarden, and D. S. Fredrickson, ch. 20, pp. 413-425. McGraw-Hill, London and New York.
Frimpter, G. W., Greenberg, A. J., Hilgartner, M., and Fuchs, F. (1967). Cystathioninuria. American fournal of Diseases of Children, 113, 115-118.

Frimpter, G. W., Haymovitz, A., and Horwith, M. (1963). Cystathioninuria. New England fournal of Medicine, 268, 333-339.

Gaull, G. E., Rassin, D. K., and Sturman, J. A. (1969). Enzymatic and metabolic studies of homocystinuria: effects of pyridoxine. Neuropädiatrie, 1, 199-226.

Harris, H., Penrose, L. S., and Thomas, D. H. H. (1959). Cystathioninuria. Annals of Human Genetics, 23, 442-453.

Laster, L., Spaeth, G. L., Mudd, S. H., and Finkelstein, J. D. (1965). Homocystinuria due to cystathionine synthase deficiency. Annals of Internal Medicine, 63, 1117-1142.

Lowry, O. H., Rosebrough, N. J., Farr, A. L., and Randall, R. J. (1951). Protein measurement with the Folin phenol reagent. fournal of Biological Chemistry, 193, 265-275.

Lyon, I. C. T., Procopis, P. G., and Turner, B. (1971). Cystathioninuria in a well baby population. Acta Paediatrica Scandinavica, 60, 324-328.

Mudd, S. H., Finkelstein, J. D., Irreverre, F., and Laster, L. (1965). Transsulfuration in mammals. Microassays and tissue distributions of three enzymes of the pathway. Fournal of Biological Chemistry, 240, 4382-4392.

Perry, T. L., Hardwick, D. F., Hansen, S., Love, D. L., and Israels, S. (1968). Cystathioninuria in two healthy siblings. New England Fournal of Medicine, 278, 590-592.

Scott, C. R., Dassell, S. W., Clark, S. H., Chiang-Teng, C., and Swedberg, K. R. (1970). Cystathioninemia: a benign genetic condition. Fournal of Pediatrics, 76, 571-577.

Tada, K., Yoshida, T., Yokoyama, Y., Sato, T., Nakagawa, H., and Arakawa, T. (1968). Cystathioninuria not associated with vitamin $\mathrm{B}_{8}$ dependency: a probably new type of cystathioninuria. Tohoku fournal of Experimental Medicine, 95, 235-242. 